\title{
O gênero fanzine-zine na sala de aula: leitura, arte e super-heróis
}

Luciane de Paula"

Josiani Kely Milesk**

\section{Resumo}

Leituras de enunciados voltados às culturas juvenis contemporâneas convocam professores e pesquisadores a olharem a linguagem e seu ensino por novas perspectivas, e essa é a relevância desta reflexão. Este artigo objetiva discutir as representações de corpos, gêneros e raças em fanzines-zines, produzidos em sala de aula, a partir dos motes "Tarsila e toda a nossa brasilidade", "Leitura \& Literatura" e "Super-Heróis". As propostas foram definidas em conjunto com os estudantes envolvidos (do ensino fundamental de uma escola da rede pública estadual de Marília, SP). A pesquisa se ancora nos estudos bakhtinianos e propõe produções a partir dos multiletramentos. As reflexões se pautam em intervenções prototípicas e as discussões sinalizam possibilidades para o trabalho com esse gênero na escola, uma vez que o zine promove leituras ágeis e produções autorais. Os resultados remetem à valorização das vozes dos alunos, que reverberam suas visões de mundo, expressas a partir de seus heróis.

Palavras-chave: Zines. Gêneros discursivos. Leitura. Arte. Estudos bakhtinianos.

\section{Considerações iniciais}

A linguagem é compreendida por nós como um ato social, enunciada por múltiplas semioses. A configuração plural das semioses em circulação hoje ocorre não somente nas mídias audiovisuais e digitais, mas também em enunciados impressos. As imagens, os arranjos de diagramação, as cores, o texto verbal escrito e oral, as sonoridades, entre outras linguagens combinadas, compõem a enunciação na produção de sentidos. A contemporaneidade, de maneira intensa, configura-se pela saturação de síncreses entre linguagens, nas mais variadas combinações de suas dimensões ${ }^{1}$ e isso

\footnotetext{
Professora da Universidade Estadual Paulista (Unesp), lotada no Departamento de Estudos Linguísticos, Literários e da Educação (DELLE), do Câmpus de Assis, e credenciada no Programa de Pós-Graduação em Linguística e Língua Portugesa do Câmpus de Araraquara, assim como no Programa de Metrado Profissional em Letras - ProfLetras, na Unidade da Unep. E-mail: lucianedepaula1@gmail.com

** Aluna de Mestrado do Programa de Mestrado Profissional em Letras - ProfLetras, Unidade da Unesp e professora do ensino fundamental em escola pública do estado de São Paulo. E-mail: kellynhamileski@gmail.com
}

Data de submissão: set. 2020 - Data de aceite: nov. 2020 http://dx.doi.org/10.5335/rdes.v16i3.11524 
exige ainda mais "capacidades e práticas de compreensão e produção" (ROJO; MOURA, 2012, p. 19) de cada uma das semioses, que Rojo e Moura denominam como "multiletramentos".

Quando a escola se restringe aos letramentos canônicos, ela deixa de cumprir com sua maior função: a formação global crítica cidadã, uma vez que desconsidera o know how dos sujeitos e limita-se a apenas alguns gêneros e registros considerados por um determinado grupo social como "adequados" em detrimento da variedade e da pluralidade de tantos outros. Com isso, promove exclusões sociais ao invés da inclusão na qual deveria se pautar para promover liberdade e autonomia reflexiva (FREI$\mathrm{RE}, 1997,2019)$. O exercício ao qual nos propomos aqui é exatamente o oposto, $o$ de dar vez e voz aos alunos, a partir de seus valores, olhares e mundos.

Ao pensarmos o processo de ensino-aprendizagem, a sala de aula e os sujeitos que a compõe, surge outra questão fundamental nessa esteira que caracteriza a pedagogia dos multiletramentos: as culturas de referência dos alunos, geralmente desprestigiadas na escola. Essa pedagogia intenta desenvolver a potencialidade crítica, pluralista, ética e democrática dos estudantes, tão cara a uma sociedade constituída por diversidades. Nesse cenário, os "pares antitéticos - cultura erudita/popular, central/ marginal, canônica/de massa - já não se sustentam mais [...]" (CANCLINI apud ROJO; MOURA, 2012, p. 15), pois a configuração contemporânea - da sociedade da hipermodernidade, do cansaço e da transparência (HAN, 2014, 2017, 2019); fluida (BAUMAN, 2007) - abre espaço aos gêneros híbridos, mestiços, desterritorializados, descolecionados (CANCLINI, 2013), que os sujeitos (BAKHTIN, 2010) criam e (re)criam, apoiados, muitas vezes, pelas tecnologias digitais, que requerem dos produtores novas éticas e estéticas, com critérios valorativos e emotivo-volitivos singulares. Subsistem, nesse contexto, uma gama de culturas juvenis, que convivem intensamente com enunciados multimodais materializados nos mais variados gêneros discursivos.

A Base Nacional Comum Curricular (BNCC) (BRASIL, 2018) para o ensino fundamental discorre sobre a necessidade de uma abordagem discursiva da linguagem com relação à "Língua Portuguesa", procurando direcionar os professores da área e as instituições de ensino a desenvolverem um trabalho que contemple as demandas da hipermodernidade, período de liquidez nas relações sociais, com atividades colaborativas de produção, nas quais as práticas de linguagem se transformam constantemente. Embora não explicite, os aspectos discursivos imbricados no trabalho com os gêneros, a BNCC os menciona, com ênfase a diferentes gêneros, (em destaque, os digitais). 
Para que a escola se torne uma "agência de letramentos" (ROJO; MOURA, 2012), é basilar observar, além da multiculturalidade, a multimodalidade enunciativa apropriada pelos estudantes nas variadas esferas, assim como trazer à cena da escola temas que propõem discussões ancoradas na realidade e de relevância social, com a inclusão de gêneros que dialoguem com o perfil do novo alunado (jovens muito atraídos pela multimodalidade, pelas mídias digitais, pelo dinamismo do ciberespaço e pelos enunciados que nele circulam). Vigoram, nas vivências juvenis contemporâneas, formas de interação ágeis, com leituras fluídas, escritas objetivas e instantâneas, correlacionadas a outros enunciados, ao compartilhamento de ideias e gêneros de diferentes semioses.

As práticas sociais de linguagem, redesenhadas pelas mídias digitais, modificam e recombinam modalidades e conteúdos provenientes de quaisquer mídias (topológicas ou tipológicas), fazem surgir discursos cada vez mais híbridos, seja em suas versões impressas seja nas digitais. Nesse sentido, acrescenta Rojo (2013, p. 20-21) que:

Esses "novos escritos" obviamente dão lugar a novos gêneros discursivos, quase diariamente: chats, páginas, twits, posts, ezines, epulps, fanclips etc. E isso se dá porque hoje dispomos de novas tecnologias e ferramentas de "leitura-escrita", que, convocando novos letramentos, configuram os enunciados/textos em sua multissemiose ou em sua multiplicidade de modos de significar. São modos de significar e configurações, como disse Beaudouin, que se valem das possibilidades hipertextuais, multimidiáticas e hipermidiáticas do texto eletrônico e que trazem novas feições para o ato de leitura: já não basta mais a leitura do texto verbal escrito - é preciso colocá-lo em relação com um conjunto de signos de outras modalidades de linguagem (imagem estática, imagem em movimento, som, fala) que o cercam, ou intercalam ou impregnam. Inclusive, esses textos multissemióticos extrapolaram os limites dos ambientes digitais e invadiram hoje também os impressos (jornais, revistas, livros didáticos).

Como explicitado, a linguagem digital não apenas transforma os enunciados que transitam nas esferas virtuais, mas influencia a configuração dos impressos, ao revelar elementos gráficos (imagens estáticas, diagramação), assim como símbolos próprios das linguagens digitais (a exemplo das hashtags, emoticons, emojis, entre outros), devido aos processos de digitalização, nos quais ocorrem a incorporação, a alteração, a redução, a ampliação e recortes de qualquer conteúdo informativo. As diferenças entre letramentos e multiletramentos podem ser compreendidas pelo primeiro como o envolvimento de variados letramentos (literário, científico, digital), que sinalizam as variedades de práticas letradas, valorizadas ou não pela escola; enquanto o segundo aponta para a junção da multiplicidade cultural com a multimodal. Já temos refletido sobre o ensino-aprendizado multiletrado, tanto em nossas práticas quanto em nossas pesquisas 
(afinal, pesquisa e educação caminham juntas), como em Paula, Barissa e Ribeiro (2019), Paula e Gonçalves (2020) e Paula e Zandonadi (2020), por exemplo.

$\mathrm{Na}$ esfera da educação, ainda predominam práticas mecanizadas de ensino de língua, com enfoque gramatical, num viés formal e estruturalista. A insistência por maneiras padronizadas de leitura e escrita, com uma abordagem restrita de gêneros, tipicamente escolarizados, não reflete as práticas sociodiscursivas, pois compatíveis com modelos pré-estabelecidos, desconectados das vivências dos estudantes e revelam um ensino artificial e ineficaz, que provoca o silenciamento de vozes e ideologias, o que aparta as práticas de linguagem reais das que se encontram na escola.

Rojo (2013) explica que as competências dos tempos giram em torno das habilidades dos alunos em deliberarem sobre questões desafiadoras e emblemáticas e equilibrarem-se nas negociações solicitadas pela diversidade, sendo a escola um território de embates, de cunho ideológico, identitário, cultural e social entre os sujeitos que a constituem. A autora preconiza um novo paradigma para o ensino e o trabalho com a linguagem:

No campo específico dos multiletramentos, isso implica negociar uma crescente variedade de linguagens e discursos: interagir com outras línguas e linguagens, interpretando ou traduzindo, usando interlínguas de certos contextos, usando o inglês como língua franca; criando sentido da multidão de dialetos, acentos, discursos, estilos e registros presentes na vida cotidiana, no mais pleno plurilinguismo bakhtiniano. Ao invés da gramática como norma para a língua padrão, uma gramática constrativa que, como Ártemis, permite atravessar fronteiras. (ROJO, 2013, p. 17).

A entrada de um gênero discursivo multimodal "estranho" à escola, como o fanzine-zine, analisado aqui, garantiu não só o debate das temáticas recorrentes e pertinentes no âmbito local, mas também, permitiu que os sujeitos pudessem eleger suas estéticas, éticas e conteúdos composicionais, marcando suas autorias e fazendo ressoar suas vozes. Essa prática envolveu a multiculturalidade e a multimodalidade enunciativa, tanto em sua produção quanto na leitura de enunciados que orbitaram os projetos didáticos, pensados nos moldes de protótipos de ensino² (ROJO; MOURA, 2012).

A intervenção realizada por nós ocorreu no segundo semestre de 2019, em uma escola pública periférica da cidade de Marília, SP, e envolveu 4 salas do ensino fundamental II vespertino, sendo 2 sétimos e 2 nonos anos. Cada turma tinha, em média, 35 alunos (logo, 70 alunos por ano) e as temáticas foram escolhidas a partir do universo dos estudantes, junto com eles. Por isso, a realização ocorreu da seguinte maneira: "Leitura, compartilhe essa ideia", tema eleito pelos sétimos anos; "Tarsila e toda a nossa brasilidade" e "Super-Heróis", escolhidos pelos nonos anos. As atividades, que envolveram a 
maioria dos estudantes (livres para o engajamento ou não, por estímulo), resultaram nas seguintes produções, por tema: $7^{\circ} \mathrm{A}, 19$ e $7^{\circ} \mathrm{B}, 25$ (sobre leitura); $9^{\circ} \mathrm{A}, 13$ e $9^{\circ} \mathrm{B}, 23$ (sobre Tarsila); $9^{\circ} \mathrm{A}, 17$ e $9^{\circ} \mathrm{B}, 20$ (sobre super-heróis), num total de 44 produções sobre Leitura, 37 sobre Tarsila e 36 sobre super-heróis.

Dentre os gêneros sugeridos pela BNCC, trabalhamos, na ação interventiva analisada, com o fanzine-zine, e, posteriormente, o e-zine (versão digital), para abarcar atividades de leitura e escrita, vinculadas a situações reais de vida no contexto local, sendo: (i) necessidade de incentivo à leitura e acesso à Sala de Leitura; (ii) estudo do legado artístico de Tarsila - II Mostra de arte e cultura da escola; (iii) proposta didática sugerida no material de apoio ao currículo (SEE/SP-Seduc). O gênero entra em cena ao cumprir funções sociais e, ao mesmo tempo, ao promover a capacidade criativa, crítica e as valorações dos sujeitos envolvidos frente aos motes e conteúdos estudados.

A concepção bakhtiniana de gêneros (BAKHTIN, 2016), assumida por nós no percurso das atividades e, agora, das análises, considera as práticas sociais e se caracteriza por sua forma relativamente estável de enunciar (composta por um conteúdo temático, uma forma composicional e um estilo, tanto genérico quanto autoral), elaborada nas esferas de interação (BAKHTIN, 2016), bem como assumimos a aula como acontecimento (GERALDI, 2010).

As produções cumpriram funções de conscientização e fomento à prática da leitura, compuseram uma exposição de arte (a II Mostra Cultural) da escola, e, por fim, ampliaram o acervo da sala de leitura, alinhadas ao interesse e gosto dos alunos. Desse modo, tentamos garantir que uma variedade de gêneros discursivos, entendidos como "entidades de vida", estejam presentes no ambiente escolar.

Neste artigo, apresentamos o gênero fanzine-zine, como procedemos para trabalha-lo na escola e analisamos, a partir do que Saffioti (1987) denominou como "nó patriarcado-racismo-capitalismo", o trinômio "gênero, raça e classe" (DAVIS, 2016) pela questão dos corpos retratados nas produções dos sujeito-alunos. Os resultados revelaram a produtividade da abordagem discursiva dialógica multiletrada nas aulas.

\section{O fanzine-zine na hipermodernidade hipercultural multimodal}

As mudanças nas interações sociais implicam em transformações das práticas de leitura e escrita dos sujeitos. As novas formas de se comunicar e conceber a linguagem não param de se renovar e nos remetem aos conceitos de modernidade, pós modernidade e hipermodernidade, assim como a concepções 
de leitura e escrita nesses contextos. A modernidade (CORACINI, 2005) está baseada em ideias iluministas, período em que imperam a racionalidade, a ciência, o progresso e no qual o homem vive um processo de encontro consigo mesmo. Já a pós-modernidade nos apresenta outra configuração de mundo: pós-panóptico (sinóptico), híbrido, complexo e confuso, enquanto a hipermodernidade se pauta no desenvolvimento técnico-científico digital da sociedade neoliberal narcísica. Segundo Lipovetsky (2004, p. 26),

[...] uma sociedade liberal, caracterizada pelo movimento, pela fluidez, pela flexibilidade; indiferente como nunca antes se foi aos grandes princípios estruturantes da modernidade, que precisaram adaptar-se ao ritmo hipermoderno para não desaparecer.

Mesmo com aspectos diferentes, as perspectivas se interpenetram, como fases da modernidade. A solidez do capitalismo se contrapõe à liquidez (BAUMAN, 2001) da hipermodernidade, em que assistimos a solvência das redes normativas e o nascimento de relações mais inconstantes, híbridas e etéreas, por uma cultura do excesso, em que todas as coisas se tornam urgentes. O movimento é uma constante e as mudanças ocorrem em um ritmo desenfreado, no qual a flexibilidade e a fluidez aparecem como tentativas de acompanhar a velocidade. Daí a prefixação “-hiper”: hipermercado, hiperconsumo, hipertexto, hipercorpo. Tudo elevado à máxima potência, numa moderação aparentemente transparente e artificialmente "feliz", o que estafa e adoece (HAN, 2014, 2017, 2019). A hipermodernidade (LIPOVETSKY, 2004) da hiperculturalidade (HAN, 2019) e da hipermídia alterou o modo como as pessoas se relacionam com a leitura, a linguagem, o conhecimento e a educação (ROJO; BARBOSA, 2015).

Essa conjuntura afeta as relações, os gêneros, os textos/discursos, os interesses e as percepções dos sujeitos frente a questões provenientes das tensões (como desigualdades, intolerâncias, preconceitos - raciais, de gêneros, de classe etc. - e comportamentais). Isso requer posturas abertas e atos de leitura que extrapolem a decodificação, pois demandam sobrecodificação (BARTHES, 2004), uma vez que envolve a interação e a significação. A construção de sentidos ocorre nas relações entre sujeitos e discursos, constituída no solo social, com sua historicidade e ideologia. $\mathrm{O}$ ato de ler e escrever, nesse cenário, é revolucionário, pois interpretativo e transformador.

Ao tratar do texto/discurso, não nos restringimos ao verbal, mas também ao não-verbal (pintura, música, fotografia etc.) e ao sincrético (canção, filme, seriado, $\mathrm{HQ}$ etc.), que pode ser lido de diversos ângulos, com visões de mundo e pontos de vista diferentes. $\mathrm{Na}$ hipermodernidade/hiperculturalidade, a multimodalidade tem sido explorada cada vez mais, com produções excessivas 
e circulação que nos bombardeia o tempo todo - principalmente, ao pensarmos no contexto contemporâneo 24/7 (CRARY, 2016). Nesse sentido, o gênero fanzine-zine figura uma oportunidade de trabalho com a linguagem que envolve essa multissemiose, pois composto de maneira multimodal/verbivocovisual (PAULA, 2017; PAULA; SERNI, 2017; PAULA; LUCIANO, 2020a, 2020b, 2020c, 2020d) (arquitetado por imagens, textos verbais, diagramações variadas etc.).

Durante a primeira metade do século $\mathrm{XX}$, os aficionados por histórias em quadrinhos (HQs) e literatura de ficção científica, nos Estados Unidos (EUA), começam a produzir publicações independentes, no formato de revistas autorais, que remetem aos pulp magazines ${ }^{3}$ (pulp fiction) das décadas de 20 e 30 (MAGALHÃES, 2018), com características estilísticas semelhantes aos panfletos anarquistas.

Os primeiros fanzines eram dominados por personagens de HQs e se constituíam como releituras ou continuações das histórias que os fãs liam. Além disso, eram usados para compartilharem informações entre as comunidades de fãs ${ }^{4}$. Magalhães explica a constituição do gênero pelo signo ideológico (VOLÓCHINOV, 2013, 2017) que o nomeia:

A palavra fanzine é a contração dos termos ingleses fanatic e magazine, significando magazine do fã. O fanzine é uma publicação independente e amadora, (...) editado por fãs (...), para um público aficionado (MAGALHÃES, 2018, p. 16).
Com o tempo, o gênero se abre para outros conteúdos (da sub-cultura e das comunidades periféricas), assumindo novos contornos. Uma vez em outras comunidades, passou a ampliar as temáticas, além da ficção científica e da fantasia. Há controvérsias quanto ao uso dos termos zine e fanzine. Resguardadas as peculiaridades, há quem defenda, como Magalhães, que se trata de um só gênero.

O termo zine é mais usual na contemporaneidade, não só devido à flexibilidade temática que abriga, mas também à tendência à economia linguística. Assuntos de interesses emblemáticos de sujeitos e/ou grupos específicos passaram a predominar nessas publicações, não mais classificadas como propriamente de fãs. Um zine que trate a questão do bullying; um que ofereça sugestões sobre o que fazer nas férias; ou ainda um que defenda interesses de uma comunidade frente a algum problema social ou político são exemplos temáticos. O compartilhamento sobre a sua produção, nas mídias digitais e redes sociais, onde se reúnem comunidades fanzineiras, é uma ação comum.

A breve historicização do zine e as ilustrações de alterações temáticas e formais mencionadas demonstram o carácter "relativamente estável" (BAKHTIN, 2016) do gênero, que se consolidam ou alteram (parcial ou totalmente) pelas condições de uso, as interações e, no 
caso, as tecnologias (especialmente, as plataformas digitais).

Essas flutuações atendem a necessidades de grupos de culturas variadas. Os fanzines ou zines são marcados por uma característica fundamental: a publicação independente. Não constitui nosso objetivo encaixá-los num formato rígido, fechado e definido. Por essa razão, usamos as expressões fanzines-zines, com vistas às especificidades expostas e derivações caracterizadoras, num movimento pendular que nos orienta por um dos elementos que constroem os gêneros: sua composição temática.

Os zines contemporâneos semiotizam vozes de grupos invisibilizados e em situações de vulnerabilidades (ativistas negros, feministas, LGBTs, estudantes, pacifistas e grupos de resistência às ditaduras na América Latina, por exemplo). No processo de desterritorialização (CANCLINI, 2013), surgem novas práticas culturais, por meio da profusão de discursos produzidos por demandas represadas de vozes de sujeitos diversos, que não encontram pertencimento e lugar de fala (RIBEIRO, 2019) em outros campos. Com a massificação da fotografia (hoje, qualquer aparelho de celular a produz) e a facilidade de acesso a novas tecnologias de reprodução (como serviços de fotocópia) ou a elaboração de sua versão digital (e-zine), as possibilidades de sua criação na sala de aula aumentaram e se tornam oportunas.
A escola onde ocorreu a intervenção prototípica realizada por nós reúne uma diversidade cultural considerável, jovens diversos em suas identidades, gostos, classes sociais, por isso, o fanzine-zine pode ser um gênero "familiar" aos estudantes que podem expressar seus modos de ver, sentir, pensar e reinventar a arte, a leitura e seus super-heróis. A partir dos eixos temáticos mencionados, ancorados em situações sociais reais, vinculados a um propósito no contexto local, os alunos criaram suas produções. Embora a escola em questão (e a pública em geral) nos apresente poucos recursos materiais e suportes tecnológicos, tais limitações não impediram a confecção das produções, uma vez que os estudantes, com criatividade e aproveitamento de materiais, contornaram a carência, motivados por propósitos vivenciais e desafios locais (tais como: o problema do acesso à sala de leitura da própria escola e a consequente falta de leitura pelos jovens nesse ambiente; a participação na II Mostra de Arte e Cultura, proporcionando maior visibilidade aos trabalhos; e a própria abordagem temática e genérica pelo currículo de língua portuguesa). Mas, como compreendemos e trabalhamos os temas escolhidos? $\mathrm{Na}$ vida e na escola. 


\section{Os zines em cena na escola e na vida}

Bakhtin (2015, 2016, 2017, 2018, 2019), Medviédev (2012) e Volóchinov $(2013,2017)$ refletem sobre os elementos da construção dos gêneros discursivos e se voltam ao acabamento como um dos elementos constitutivos dos gêneros, não relacionado apenas às questões convencionais e composicionais. Para os autores, a temática se liga à totalidade construtiva tridimensional (signo-enunciado-discurso) de uma obra:

Um tema transcende sempre a língua. Mais do que isso, o tema não está direcionado para a palavra, tomada de forma isolada, nem para a frase e nem para o período, mas para o todo do enunciado como apresentação discursiva. O que domina o tema é justamente esse todo e suas formas, irredutíveis a quaisquer formas linguísticas. O tema de uma obra é o tema do todo do enunciado, considerado como determinado ato sócio-histórico [sic]. Por conseguinte, o tema é inseparável tanto do todo da situação do enunciado quanto dos elementos linguísticos. (MEDVIÉDEV, 2012, p. 196).

Ao nos voltarmos aos zines, as cores, as imagens (ilustradas ou recortadas), os registros verbais, a diagramação escolhi$\mathrm{da}$, entre outros elementos, evidenciam o caráter tridimensional da linguagem, explicitamente expresso pela verbivocovisualidade (PAULA, 2017; PAULA; SERNI, 2017; PAULA; LUCIANO, 2020a, 2020b, 2020c, 2020d) dos enunciados produzidos como dimensões que compõem a unidade arquitetônica do gênero, dentre os demais, também em torno do acabamento temático.

Além disso, esse gênero discursivo ocupa lugares concedidos pela vida, que operam conteúdos temáticos conectados a esse tempo e espaço. Atuam na cultura e sociedade na qual circula, como um corpo vivo. Enquanto corpo verbivocovisual (PAULA, 2017; PAULA; SERNI, 2017; PAULA; LUCIANO, 2020a, 2020b, 2020c, 2020d), produzido por sujeitos organizados de determinada forma, em condições de realização e recepção, instaura-se como resposta posicionada de existências, que permitem reflexo e refração em seu próprio corpo, junto aos corpos trazidos em suas propostas enunciativas.

Os eixos temáticos propostos para elaboração dos zines orientam questões vivenciais da cultura contemporânea e da comunidade escolar, com ressignificações de corpos vindos da arte (Abapuru, Operário, A negra), assim como do universo das HQs (os super-heróis), além de corpos que os alunos concebem como os de um "leitor" e de suas escolhas de imagens representativas da esfera literária.

No primeiro momento, partimos de uma situação-problema que movimentava os alunos dos $7^{\circ}$ anos: a falta de interesse pela leitura entre colegas de outras classes e o restrito acesso à Sala de Leitura da escola, sobretudo devido à ausência de um profissional responsável 
por esse espaço de conhecimento. Depois de rodas de conversa e diálogos com os alunos, verificamos a necessidade de organizar uma ação que promovesse o incentivo à leitura no âmbito escolar, com o uso dos livros do acervo, a fim de ressignificarmos os tempos e espaços para as atividades de leitura na escola. Coletivamente, ampliamos o espaço para leitura nas aulas de Língua Portuguesa, ao elegermos 1 aula semanal para essa atividade na Sala de Leitura.

As ações tiveram a anuência da coordenação pedagógica da escola e foram elencadas nos planos de ensino. Durante as rodas de conversa, os alunos sugeriram o início de um trabalho massivo de divulgação de suas leituras por meio de cartazes espalhados pela escola. Após as discussões, decidimos, coletivamente, iniciar uma atividade com o gênero zine, nunca visto em cena na escola, por meio do qual poderiam promover a leitura na comunidade escolar e fora dela, divulgando seus projetos de dizer.

Num outro momento, a partir dos fanzines, desenvolvemos um trabalho com a temática "Tarsila e toda a nossa brasilidade", que constituiu o mote da II Mostra de Arte e Cultura da escola. O tema proposto para o trabalho interdisciplinar surgiu a partir de uma vivência da diretora da escola, em visita ao MASP - Museu de Arte de São Paulo. Na oportunidade, a gestora pode contemplar a mostra "Tarsila Popular".
Logo, vislumbrou a possibilidade da abordagem do legado artístico da pintora Tarsila do Amaral entre os estudantes. Já na escola, replicou sua vivência junto ao corpo docente, que acolheu a proposta e percebeu o quanto o tema e as obras de Tarsila poderiam enriquecer o repertório artístico-cultural dos estudantes, além de, em muitos aspectos, relacionar-se aos conteúdos de várias áreas, não só de linguagens. As atividades foram planejadas por todas as disciplinas e, nas aulas de Língua Portuguesa, propomos a elaboração de fanzines temáticos que retratassem, além das releituras das obras, a perspectiva dos sujeitos frente o conjunto artístico da pintora brasileira.

A última ação pedagógica analisada, baseou-se em sequências de atividades do material de transição proposto pela Coordenadoria de Gestão da Educação Básica (CGEB), da Secretaria Estadual da Educação (SEE/SP), referente ao ensino de língua portuguesa, no $4^{\circ}$ bimestre, nos nonos anos de 2019. Estruturou-se em torno do tema "Super-Heróis" no contexto da aula, a partir de um breve relato da vida de Stan Lee ${ }^{5}$. A sequência proposta no caderno do aluno de língua portuguesa se destinou a complementar as aulas da disciplina durante o período de transição, que se deu no ano letivo de 2019, até que fosse implementado o Novo Currículo Paulista para o ensino fundamental II, em consonância com a nova BNCC, aprovada em 2018. 
Assumimos, na ação interventiva prototípica mencionada, a concepção dialógica da linguagem. $\mathrm{O}$ estudo da língua ocorreu na e em interação, manifesto por enunciados situados em uma realidade e em um contexto social. A ação metodológica da atividade ocorreu norteada pela alteridade e pelo cotejo, de maneira qualitativo-interpretativa.

Articulamos a ideias, na busca de diferentes saberes sobre os objetos, com vistas a discutir as representações dos corpos, gêneros e raças nos fanzines-zines analisados, considerando as três temáticas norteadoras. Além do gênero eleito (visto como um corpo vivo), analisamos como os estudantes concebem, como autores-criadores, os corpos (artístico-fantástico-literário) em seus enunciados, assim como ilustram as questões raciais e de gênero a partir de seus olhares singulares, suas vivências particulares, suas identidades e ideologias. Com o cotejo, tanto na ação em curso, quanto na análise dos elementos produzidos após a confecção dos zines, pudemos verificar o que envolveu suas escolhas conteudísticas, formais e estilísticas, com espaço para novos temas, contextos e sentidos. A constituição dos enunciados e dos sujeitos se deu a partir do diálogo com outros enunciados, em um processo constante de embates.

A atividade e este estudo ocorreram por meio da pesquisa interventiva, de natureza qualitativa, com produção e coleta de dados, análise de corpus e ação pedagógica. Foram analisadas as produções dos alunos, relacionando teoria e prática, considerando as subjetividades e os posicionamentos dos sujeitos em atos.

Durante as intervenções, conduzimos os sujeitos por leituras diversas: livros, tutoriais do YouTube, páginas de comunidades fanzineiras na internet, uma breve abordagem da bibliografia de Tarsila do Amaral, do movimento modernista no Brasil e sua obra artística, trailers de filmes de super-heróis e imagens estáticas de revistas, o que provocou, por meio do cotejamento, a expansão do repertório de linguagens, cultural e das relações entre as leituras com o propósito da atividade. Sem perder de vista a investigação sobre como combinam a multimodalidade empregada, tanto em suas produções, quanto nos enunciados analisados no processo.

A pretensão foi estudar e construir uma prática de ensino calcada na perspectiva dos gêneros discursivos (BAKHTIN, 2016) e dos multiletramentos (ROJO; MOURA, 2012), que entram em cena, a partir da valorização da cultura local dos sujeitos, por meio da escuta do problema e da eleição do gênero pelos alunos, provocando a ampliação do repertório cultural. Os alunos/sujeitos (re)construíram suas reflexões acerca dos temas, do gênero, com seus estilos autorais. As atividades sugeridas no processo consideraram, como já dito, 
a multiplicidade de culturas, uma vez que desfez os pares antitéticos cultura central/marginal e trouxe ao centro da aula discursos multimodais (tutorial, filme curta-metragem, revistas impressas e vídeos do YouTube) de diferentes letramentos e esferas, hibridizados em suas produções, assim como o próprio zine, desconhecido na escola.

Cada sujeito elaborou sua reflexão, considerando os enunciados na cadeia discursiva estabelecida, valorando os temas, oriundos das vozes que ecoaram na arena de embates da sala, tanto entre os pares quanto dos discursos cotejados. $\mathrm{O}$ trabalho envolvendo os multiletramentos se evidenciou, uma vez que outros gêneros do discurso, vindos de esferas e constituídos por linguagens diversas começaram a circular no ambiente escolar, transformados e reelaborados criticamente, de forma responsiva.

A intervenção em análise propôs o trabalho com o protótipo de atividade, definido como "estruturas flexíveis e vazadas que permitem modificações por parte daqueles que queiram utilizá-las em outros contextos que não os das propostas iniciais"(ROJO; MOURA, 2012, p. 8). Este modelo permite inúmeras possibilidades, pois torna-se um instrumento norteador para a aula, que não restringe a liberdade de adaptações durante a execução, não desconsidera os interesses de seus alunos e não ignora as demandas emergentes de seu contexto. Ao contrário. Parte desses aspectos todos, em conjunto, como ato acadêmico, ao considerar a aula como acontecimento (GERALDI, 2010) social.

Os protótipos são flexíveis, afinal são remodelados pelo e no processo, entrelaçados com princípios de análise crítica das significações, ancorado nos multiletramentos de maneira dialógica. Adequá-los ao contexto, com as contribuições dos sujeitos-alunos, em ato social é o que os diferencia de projetos didáticos engessados. $\mathrm{O}$ cotejo fez com que os gêneros ampliassem o repertório discursivo e cultural com o todo do conhecimento, para que os sujeitos-alunos elaborassem seus projetos de dizer em suas produções com o acabamento planejado.

Com isso, os alunos foram levados a refletir sobre como, gradativamente, podem incorporar em suas práticas discursivas, escolares ou não, suas vozes sociais em diálogo com outras, em consonância com a era digital e contextos que reúnem cada vez mais a pluralidade cultural e uma sociedade multiletrada. Procedimentos de leitura e produção foram repensados, a fim de conduzirem os sujeitos à análise e transformação dos textos/discursos na forma impressa, a princípio e, depois, num zine digital.

\section{Os fanzine-zines produzidos: corpos em cena \\ O gênero discursivo exerceu funções características no processo: a primeira}


proposta temática se voltou a um "manifesto", como forma de reagir aos desafios indicados pelos alunos sobre a questão da leitura na escola. A segunda, como expressão de uma manifestação artística, elaborada pelos alunos, para exposição na mostra cultural realizada pela e na escola. E a terceira, além de fazer fruir as preferências de jovens leitores e consumidores das HQs e suas personagens, compôs uma minicoleção junto ao acervo da Sala de Leitura da escola. Durante as rodas de conversas, verificamos os anseios dos sujeitos-alunos, ponderamos sobre os desafios, colocados pelos sujeitos protagonistas por meio do diálogo. A escuta constante dos sujeitos-alunos nos permitiu perceber que, ao considerar suas opiniões, o engajamento nas etapas se tornou mais efetivo, afinal se sentiam responsáveis pelas atividades e autores de suas produções.

Realizamos durante as aulas de Língua Portuguesa atividades de análise da constituição multimodal dos objetos: capas dos livros lidos, fotogramas e cenas dos trailers de filmes assistidos. Durante a etapa de elaboração dos zines, os alunos assistiram a tutoriais no YouTube sobre a confecção do livreto e já iniciaram ensaios de escrita. Esse processo, em cada ação pedagógica, levou várias aulas, até que, ao final, os zines tomassem forma. Concomitantemente à elaboração de seus discursos e produções, os alunos analisavam as imagens pesquisadas nas revistas, avaliavam a relação com cada discurso e a pertinência do uso. Foi possível notar a mudança de olhar para o sentido de cada elemento (cores, linhas, imagens, letras, texto etc.) selecionado pelos sujeitos. Era preciso fazer sentido com sua proposta discursiva. A atividade passou a ser planejada conscientemente e as aulas, a fazerem (mais) sentido, uma vez que os estudantes disseram se sentirem contemplados ao serem ouvidos e, ao terem suas vozes legitimadas, passaram a se sentirem pertencentes àquele universo. A Figura 1 demonstra uma visão panorâmica das três coletâneas produzidas:

Figura 1 - Coletânea dos zines produzidos pelos alunos, respectivamente, com os temas "Leitura \& Literatura, "Tarsila e toda a nossa brasilidade", "Super-Heróis"

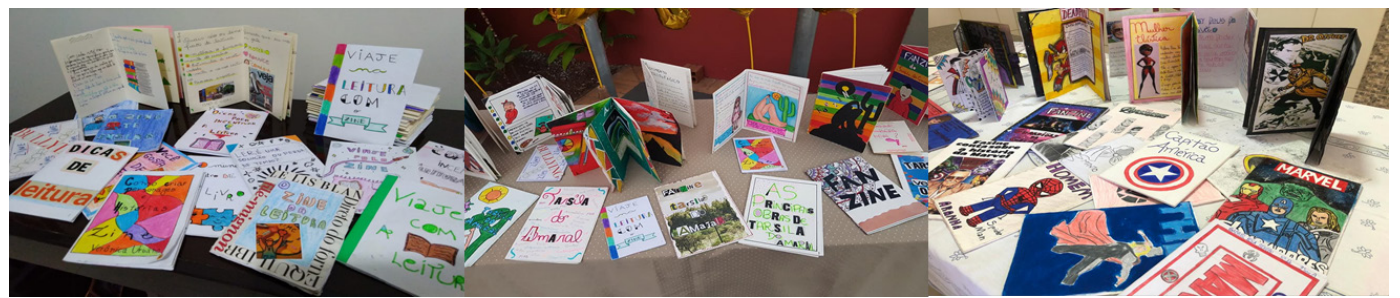

Fonte: registros fotográficos das autoras. 
Nos atentamos, aqui, em refletir sobre as representações dos corpos, a partir dos temas relacionados. Fixamos nosso olhar sobre uma pequena amostra de produções, devido ao espaço limitado do presente artigo. Para uma análise mais detida, separamos os exemplares que se centralizaram na representação de corpos, além do emprego de múltiplas semioses e a consciência a ser produzida no outro.

\section{Leitura \& Literatura: compartilhe essa ideia}

Com relação à temática da leitura, houve uma predominância de enunciados com valoração positiva frente ao ato de ler. Muitos enunciados com estrutura injuntivo-prescritiva, marcada por verbos no imperativo (como "Leia",
"Viaje"), num tom de orientação. A construção desses enunciados, induzidos pelo modelo do gênero visualizado, a priori, camuflou suas vozes, diante de uma preocupação centrada na estética e na resposta a um modelo. A preocupação com a escolha dos signos ideológicos visuais revelou o diálogo com enunciados da poética assumida. Dentre os exemplares dessa temática, o zine da Figura 2 , intitulado "Como criar personagens", chama a atenção por, apesar do tom prescritivo relacionado ao incentivo à leitura, voltar-se à criação e à produção de histórias e personagens próprios. $\mathrm{O}$ autor constrói sua composição, com ênfase a personagens femininas (gênero) e tenta equilibrar a representatividade racial, ao retratar duas garotas brancas, uma parda e uma negra:

Figura 2 - Capa e parte interna de um zine do aluno-criador 1

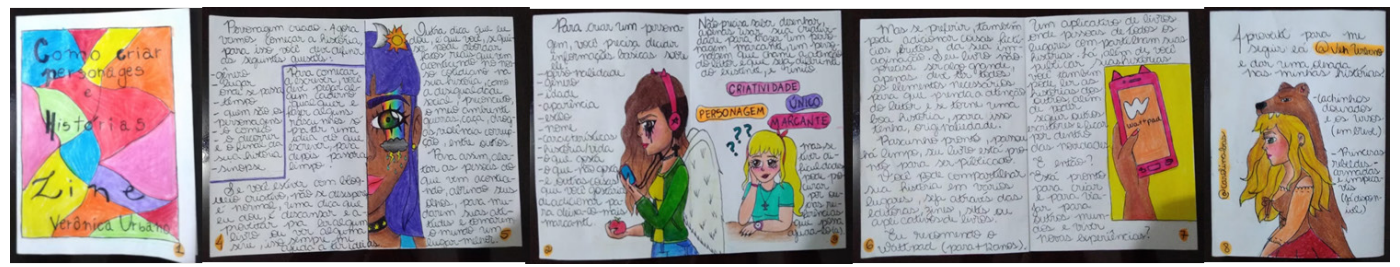

Fonte: registros fotográficos das autoras.

A primeira personagem revela uma dualidade em sua caracterização: tem asas de "anjo" e chifres de "diaba", o que remete a um perfil contemporâneo juvenil, conectado, multitarefas e híbrido (humano-anjo/demônio), sendo os símbolos religiosos (a cruz nos brincos, as asas, os chifres e a maçã) os elementos que marcam a oposição bem/mal.

Durante as atividades, evidenciamos falas dos alunos voltadas ao diálogo com personagens já existentes, mas com identidades renovadas e elementos diferentes. O enunciado verbal remete o leitor 
a explorar outras ferramentas para a criação de uma personagem ou história, com referência às plataformas virtuais de escritas autorais Wattpad, convidando-o a seguir um perfil já existente na comunidade de escritores.

Na sequência (Figura 3), as quatro capas de zines variados de mesma temática ilustram a estrutura da maioria dos exemplares criados: a tendência de construção de dicas rápidas sobre a leitura, lugares mais apropriados para ler, além de dicas de livros, associadas com a escola.
A escolha dos lexemas voltados à sala de aula (como "ensina", "leitura", "livro", entre outros) e da técnica de colagem são as opções recorrentes utilizadas na maioria das propostas. A diagramação (visual) e o cuidado com a combinação e o formato verbal revelam a arquitetônica dos zines. $\mathrm{O}$ enunciado da primeira capa "O zine te ensina”, por exemplo, completa-se com uma colagem (imagem de um livro), composta pela mensagem "Como ter êxito na vida”, num jogo verbo-visual que compõem a unidade enunciativa das produções:

Figura 3 - Capas dos zines "O zine te ensina" (aluno-criador 2), "Dicas para incentivar a leitura" (aluno-criador 3), "Viaje na leitura com o zine" (aluno-criador 4) e "O mundo dentro de um livro" (aluno-criador 5), respectivamente

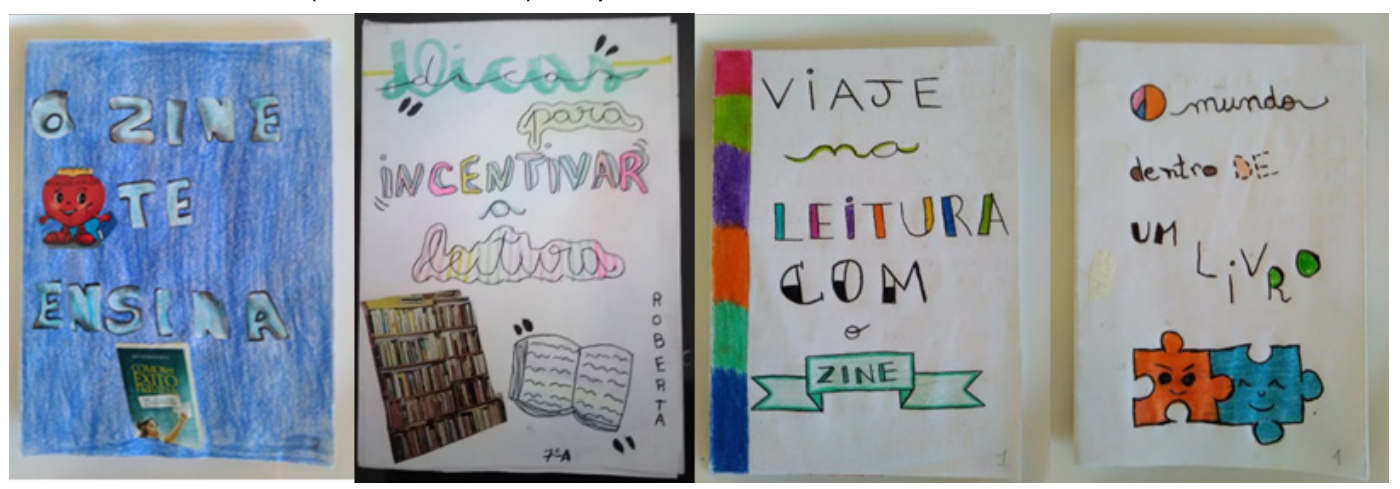

Fonte: registros fotográficos das autoras.

Nas partes internas, de vários exemplares, imagens e corpos ilustram a figura do professor, colocado como autoridade representativa de questões de leitura e literatura, responsável por apresentá-la aos alunos. Essa ideia resiste, muito embora os sujeitos encontrem e sigam outras fontes de leitura. Além dele, alguns zines remetem a autores consagrados e à profissão de escritor como referência.

$\mathrm{O}$ zine, corpo vivo que materializa temas e interesses de sujeitos igualmente vivos e responsivos, instiga e chama à cena outros assuntos, de modo que a subversão (temática) aparece, uma vez que se voltam a assuntos de interesse 
dos sujeitos que elaboraram novas propostas, relevantes a eles, o que denota o caráter versátil do gênero.

\section{Tarsila e toda a nossa brasilidade}

Este eixo temático foi desenvolvido com a finalidade de promover um evento da escola. Algumas pesquisas e estudos foram realizados junto com os estudantes, por meio dos quais puderam perceber as escolhas temáticas, formais e estilísticas de Tarsila. As obras da pintora despertaram olhares perplexos entre os alunos. A recepção do legado de
Tarsila ocorreu, a princípio, por um viés artístico, mas promoveu estudo amplo da linguagem e garantiu o estudo literário. O post-convite elaborado com os alunos, circulou nas mídias divulgando a mostra de arte e cultura da escola.

Algumas capas dos fanzines produzidos (Figura 4) pelos sujeitos-alunos ilustram que suas escolhas se centraram em releituras de obras consagradas (como: Urutu, Abapuru, Manteau Rouge, etc.), mantendo as cores vibrantes e a vivacidade da artista, sem deixar expressar seus posicionamentos e marcas autorais, inclusive com traços de culturas contemporâneas (como a street art, por exemplo):

Figura 4 - Capas dos fanzines "Tarsila Zine" (aluno-criador 10), "Abaporu Pop” (aluno-criador 7), "Tarsila do Amaral" (aluno-criador 8) e "Fanzine" (aluno-criador 11)

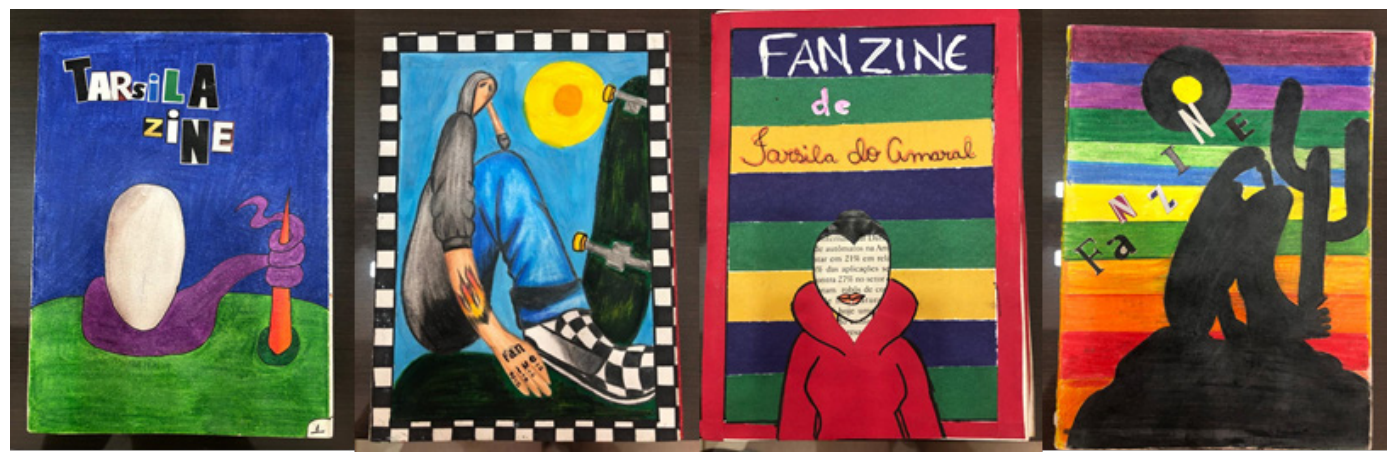

Fonte: registros fotográficos das autoras.

A tela Operários, de Tarsila, inagura a fase social da pintura brasileira. $\mathrm{Na}$ obra original são 53 cabeças que representavam os povos da Terra e, ao mesmo tempo, dentre os rostos, figuras conhe- cidas da artista, algumas delas de sua convivência, inclusive. As três reconstruções (Figura 5) utilizaram técnicas de colagens e ilustrações. 
Figura 5 - Páginas internas dos fanzines "Operários da Educação" (aluno-criador 11) e "Sem título" (aluno-criador 13) - releituras da obra Operários; e do "As principais obras de Tarsila do Amaral" (aluno-criador 12)

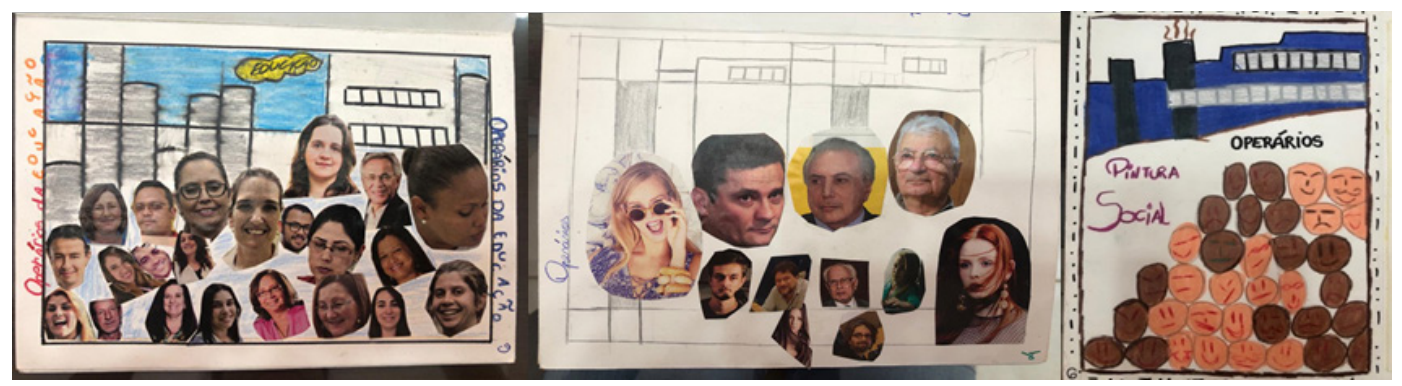

Fonte: registros fotográficos das autoras.

A releitura construída, intitulada "Operários da Educação", retrata 22 rostos, em sua maioria femininos. Questões que envolvem gênero, raça e classe refletem e refratam a realidade observada no solo social da educação hoje, rapidamente percebida pelo sujeito-aluno: em sua maioria, mulher, branca e de meia idade (características que não se diferem das representações masculinas na composição). Há uma sinalização de que a classe (professores e demais agentes da educação) é formada, predominantemente, por mulheres, vista como "operários", atuantes em "escolas-fábricas".

A nuvem de fumaça reafirma a valoração da educação como fábrica. Nela, há a inscrição "educação". Apesar das faces sorridentes, em contradição à representação do quadro-matriz, não há interação entre as pessoas, que olham para frente e, algumas, para baixo. Dos dois únicos rostos negros, um possui olhar cabisbaixo e triste.
Ao questionar o aluno-autor sobre essa escolha, ele nos respondeu que teve dificuldades para encontrar rostos de pessoas negras em revistas, mas acredita que a cena composta ilustra a realidade da esfera educacional, pelo fato de observar poucos professores negros na escola pública. Procurou mostrar, além de sua percepção de escola, ao fazer a comparação com uma fábrica, a falta de representatividade negra na reconstrução, grupo de pessoas que muitas vezes não ascende educacional e socialmente. Essa ausência contrasta com uma sociedade de expressiva população negra e miscigenada como a brasileira, fortemente marcada nas pinturas de Tarsila.

O fanzine "As principais obras de Tarsila do Amaral" traz a terceira releitura, por meio de ilustração (sem colagens). As figuras empilhadas retratam perfis indefinidos, com o corpo não revelado. Visualmente, parecem "pedras" que se sobrepõe umas às outras. Embora 
remeta a rostos, pelos traços que marcam olhos, bocas e nariz, apresentam uma homogeneização, quebrada pela cor (marrom e rosa claro) que os difere, remetendo a pessoas negras e brancas. Nesse zine, houve uma preocupação em equilibrar essas duas representatividades étnicas, em dezoito "rostos-pedras" negros e dezessete "rostos-pedras" brancos. A interpretação "pessoas-pedras" nos leva a refletir e conceber um cronotopo (tempo-espaço) de homem-imprensa: aquele massificado, objetificado, imerso em sistemas de seriação, produtibilidade, estresse e exploração em demasia (típico da hipermodernidade) que desumaniza os sujeitos e as transforma em instrumentos, em "pedras frias" em prol a manutenção de um sistema fabril, consumista e materialista, que esvazia a humanidade e força a inserção (de brancos e negros) numa sociedade em que, dadas as escalas, todos operam e são operados.

$\mathrm{O}$ segundo fanzine não foi intitulado pelo aluno. Embaixo, em uma de suas partes, há a reconstrução, a partir do enunciado-fonte, trazendo uma proposta invertida do que se espera em relação aos corpos representados, pois o autor-aluno classifica como operários, perfis pertencentes a estratos sociais privilegiados (entre eles, pessoas públicas dos ramos: político, jurídico e artístico da sociedade brasileira), num grupo drasticamente menor de sujeitos (11), se compararmos com a obra em cotejo. Pessoas brancas, bem vestidas, com feições de imposição, ostentação, indiferença e desdém. A construção ao fundo não é uma fábrica, o que pode sinalizar o lugar de pertencimento dos sujeitos retratados (privilegiado). A seguinte pergunta foi feita ao sujeito-aluno: "Por que essas pessoas são operários?". A resposta foi: “ Porque elas nos operam, manipulam". O valor semântico que o autor-aluno emprega ao usar o verbo "operar", relacionado com o substantivo-título da obra-matriz (Operários), revela uma quebra de expectativa, pois apresenta a relação do título com os valores axiológicos do sujeito.

Como já mencionado, também realizamos atividades sobre os super-heróis.

\section{Super-heróis}

Por acreditarmos que as ações pedagógicas devem partir de práticas situadas e que dialogam com a realidade e os interesses dos estudantes, desenvolvemos o presente eixo temático. Nas elaborações, os autores-alunos utilizaram recursos variados (ilustrações, colagens, pintura), em referência às personagens das HQs. Cores fortes, imagens coloridas e recortadas de revistas, foram cuidadosamente incluídas nos fanzines. Houve predominância de personagens da Marvel e da DC Comics. Ao analisarmos a coletânea de zines produzidos, notamos uma presença 
considerável de super-heroínas e seres mutantes, com corpos sexualizados. As imagens (coladas ou ilustradas) demonstram um retrato sensual das heroínas, com ângulos que valorizam partes específicas de seus corpos (busto e quadril) (Figura 6). Nos fanzines, tais personagens são recorrentes:

Figura 6 - Capas dos fanzines "Scarlet Witch" (aluno-criador 18), "As Heroínas" (aluno-criador 8) e página do fanzine "Os Incríveis" (aluno-criador 8)
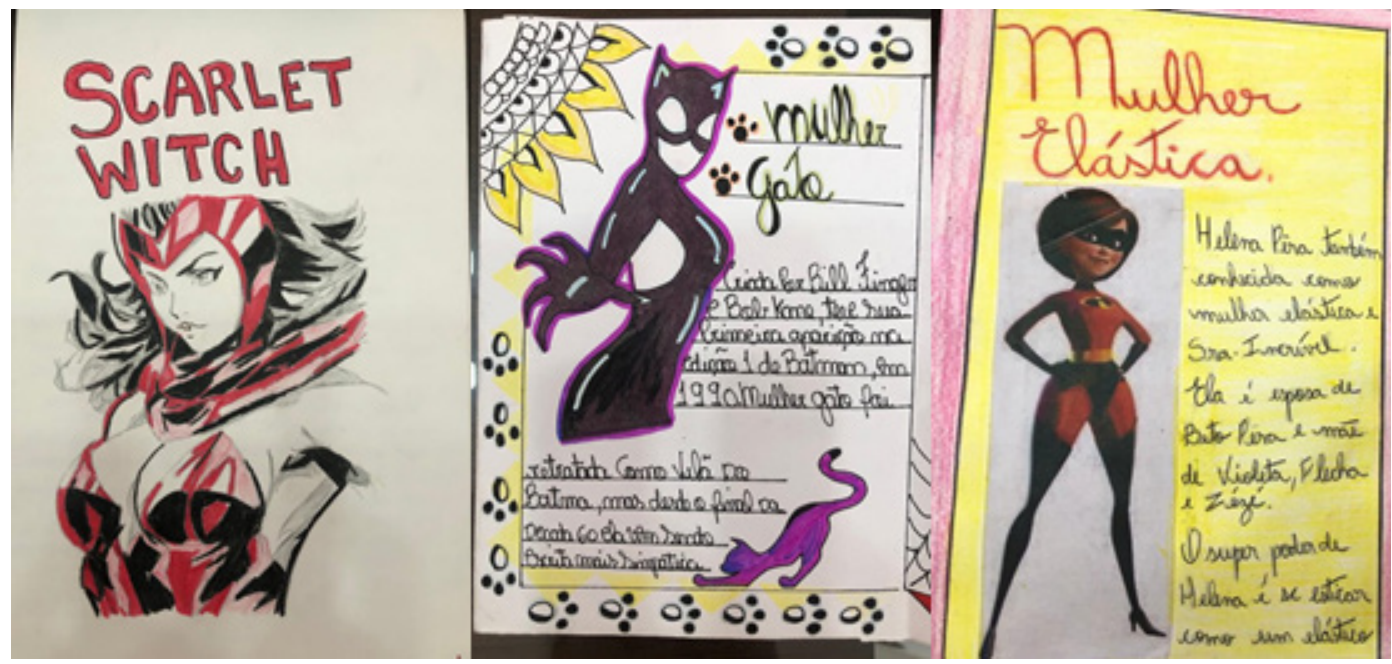

Fonte: registros fotográficos das autoras.

Scarlet Witch é alter ego ${ }^{6}$ de Wanda Django Maximoff (humana, geneticamente modificada), uma híbrida de humana e bruxa. A personagem é considerada uma das figuras mais poderosas da Marvel, com poder de controlar a magia, o caos e de manipular as probabilidades. Tais poderes dialogam com traços das habilidades da mulher contemporânea, que sofre coerções para que mantenha "controle" e esteja no "controle" de tudo, sempre. No zine, ela é ilustrada de forma imponente e altiva. A Mulher Gato, alter ego de Selina Kyle, também aparece na página do fanzine com destaque para o seu corpo. A imagem faz insinuações a sua principal habilidade: a manipulação, bastante associada à inteligência e sagacidade felina. Seus passos são retratados no entorno, o que sinaliza a maneira como age: silenciosamente, revelando uma personalidade dominadora. Ao mesmo tempo em que as personagens são colocadas como figuras empoderadas nos fanzines, as imagens também são retratadas de forma sensual e sexualizada, como aparecem nas HQs, no cinema e nos games.

A imagem de uma família tradicional, super-poderosa e feliz ainda é entendida 
como um padrão a ser alcançado. Mas, Helena Pera (Mulher Elástico ou Sra. Incrível, de Os Incríveis) é integrnate de uma família não tão perfeita assim. Helena retrata a figura de uma mulher que se desdobra para manter essa família.

No filme de animação Os Incríveis 2 , a personagem é aberta a uma inversão dos papeis, dentro de modelo social tradicional familiar, forçada a dividir-se em dupla jornada: cuidar da família e trabalhar fora, enquando o marido fica em casa cuidando dos filhos. No trailer (Figura 7), as cenas enaltecem e apre- sentam a Sra. Incrível de forma mais empoderada, assim como foi retratada na página do fanzine, com postura pró-ativa. O esteriótipo de "pai-provedor" é desconstruído e quem se sobressai na cena familiar e ocupa esse papel é a super-heroína. No trailer, há uma cena que ilustra essa posição de destaque e um certo desconforto do Sr. Incrível quando se depara com a sugestão, de uma autoridade do governo, de que a mulher elástica seria a "melhor opção" para trazer os super-heróis que foram banidos da vida social de volta.

Figura 7 - Encontro do Sr. e da Sra. Incrível com autoridade do governo da cidade
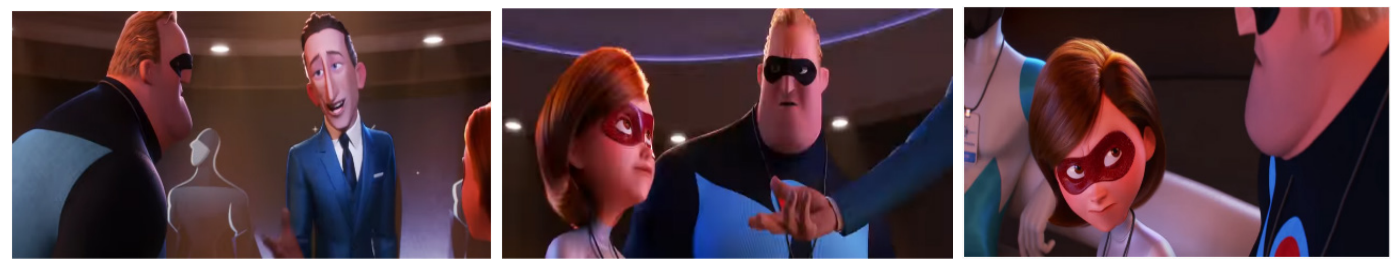

Fonte: Fotogramas de 00:00:46, 00:00:47 e 00:00:48, respectivamente, do trailer de Os Incríveis 2 (2018).

Há uma tentativa, em todo enunciado-fonte, analisado em sala de aula, de mostrar essa desconstrução hierárquica e patriarcal entre os membros da família. Os estudantes, ao mesmo tempo que riram, indignaram-se com a cena onde a condição de inferioridade do Sr. Incrível e sua reação são expostas, o que revela um posicionamento cultural machista ainda persistente (estrutural), a favor do protagonismo do herói masculino (figura paterna). O olhar assertivo e de repreensão da mulher em resposta à frase do Sr. Incrível ("Melhor do que eu?") reforça sua postura reativa, autoconfiante e empoderada. Ela defende e assume essa posição valorativa.

O fanzine "Jéssica Jones" (Figura 8) apresenta uma heroína tímida e solitária, com dilemas na vida pessoal e crises de identidade. A partir de uma narrativa em $1^{\text {a }}$ pessoa, a própria personagem vai se apresentando ao longo do fanzine e conta como se deu sua transformação em uma super-humana. A forma como foi retratada (as cores utilizadas, com ângulos de seu perfil) reafirma seu traço de personalidade. 
Figura 8 - Capa e páginas do fanzine “Jéssica Jones” (aluno-criador 7)

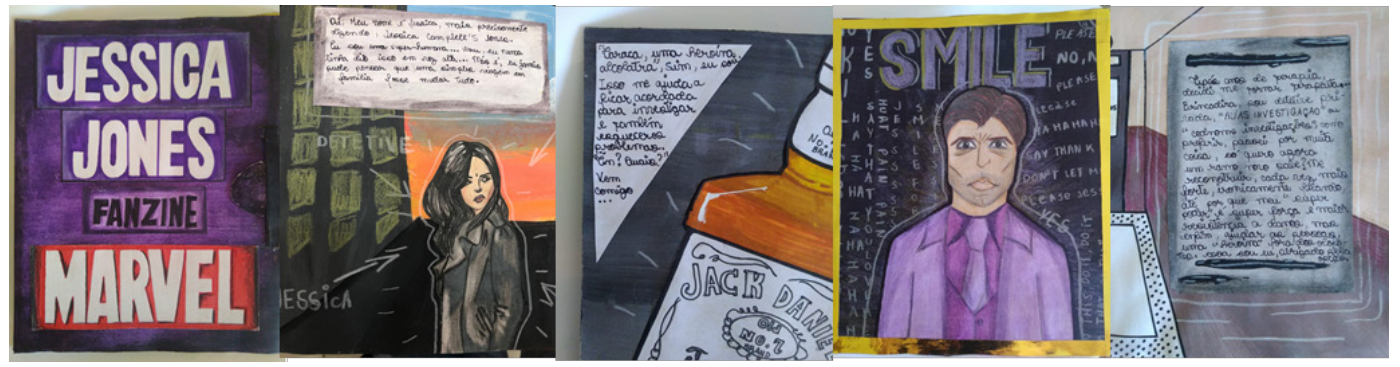

Fonte: registros fotográficos das autoras.

A produção, com técnicas de pintura, poucas colagens e mescla de tons escuros (como preto, cinza e roxo) geram uma ambientação fechada, que também dialoga com as características da heroína. Seu temperamento insconstante e suas instabilidades emocionais a conduzem ao vício em álcool, a ponto de Jéssica se intitular uma "heroína alcoólatra". Na criação do fanzine, não se explora a sensualidade centrada no corpo da figura feminina, mas se revelam as fragilidades às quais o seres humanos estão sujeitos.

O problema com o álcool é justificado pela personagem, devido a um sequestro praticado pelo Homem Púrpura, que tinha o poder de controlar mentes, e a controlou por muito tempo. Esse homem a subjugava e a forçava a dizer e a fazer coisas que não queria, até que Jones foi salva por agentes da Shield. Por essa e outras razões, precisou de ajuda psicológica, entretanto, os danos de uma trajetória de exposição a sofrimentos emocionais deixaram marcas profundas em sua personalidade. Na última pági- na, o autor-aluno do fanzine mantém o foco narrativo pela voz da personagem e encerra o relato da heroína com a revelação de seu super-poder: "a capacidade de resistência a danos". Embora aceite sua condição de heroína, não deseja esse status. Seu objetivo é ajudar as pessoas longe dos "holofotes". O reconhecimento das fragilidades (timidez, medos e inseguranças) da personagem a tornam mais humana e geram identificação e empatia nos fãs. Sua retratação, no fanzine, procurou enfocar exatamente esses aspectos que se harmonizaram com a escolhas verbivocovisuais do autor-sujeito-aluno.

A visão crítica dos alunos, com o decorrer do processo prototípico multiletrado, foi se expandindo ao passo que se sentiram seguros de poderem expor suas posições. Além disso, a diferença entre a colagem-reprodução predominante nos zines analisados no eixo temático sobre leitura e as ressignificações produzidas nos zines sobre Tarsila e os super-heróis, também se deve aos anos em que as intervenções foram realizadas. 


\section{Considerações finais}

Entender a língua e a linguagem sob a ótica bakhtiniana significa considerar as múltiplas relações e vozes sociais em embate vivo, em ato. Por isso, a constituição discursiva de cada sujeito na escola depende da riqueza da atmosfera heterogênea da vida, com a expressão plurissignificativa de vozes e multiplos letramentos.

Empreender um trabalho por meio dos gêneros discursivos, neste caso, do fanzine-zine, fez com que uma prática contemporânea de linguagem, próxima às culturas dos estudantes, circulasse na sala de aula em conjunto com conteúdos programáticos já contemplados, o que possibilitou maior riqueza e contemplou diversos imaginários. Nas leituras e nas produções realizadas com as atividades de intervenção, colocamos em cena diversos gêneros discursivos e, por meio deles, múltiplos conteúdos, diversos registros linguísticos e variadas culturas, o que possibilitou convívio com pluralidades identitárias, com suas vozes e posicionamentos variados contemplados. Esse caldeirão heterogêneo instaurou a riqueza da diversidade da vida na e da sala de aula, bem como a pluralidade e a integração transversal de conhecimentos.

O ensino-aprendizado como o proposto e realizado por nós é muito mais trabalhoso, mas também pleno, em percurso processual, ao encontro do que
Freire $(1997,2019)$ propõe como caminho à liberdade e à autonomia, uma vez que coloca o educador como um mediador-orientador que direciona/canaliza os conhecimentos, de maneira variada, contemplando sujeitos e vozes muitas vezes silenciados por práticas mecanizadas e alienantes, que não revelam suas visões de mundo, de modo legítimo.

Neste artigo, refletimos acerca das percepções de corpo em enunciados marcados pela multimodalidade, nos quais se presentificaram as dimensões verbais, vocais e visuais, em sua concretude enunciativa. Para isso, além da eleição do gênero fanzine-zine, levamos à cena escolar temas, vistos para além de meros conteúdos, formados pela tríade (forma-conteúdo-estilo - autoral e genérico), engendrando o todo de sentido dos enunciados criados pelos sujeitos-autores-alunos, ligados a uma vivência social concreta. Os motes "Leitura \& Literatura", "Tarsila e toda a nossa brasilidade" e "Super-Heróis" foram os eixos a partir dos quais, textos, obras e personagens se fizeram presentes e puderam ser lidos, experienciados e ressignificados, de maneira situada. Os interesses dos sujeitos concentraram-se em enunciados de gêneros variados, dos quais se autodesignaram ou se tornaram fãs, a partir dos quais puderam se expressar.

Na coletânea de produções, as apreciações valorativas e estéticas, além de variadas linguagens, elaboradas de modo 
autoral, contempladas pelos gêneros e pelos multiletramentos, possibilitaram a visibilidade da pluralidade de vozes e sujeitos, deu vazão heterogeneidade da sala de aula e da vida. As apreensões dos estudantes acerca de questões sociais manifestas nas formas como foram retratados os corpos representados nas obras-fontes cotejadas, foram significativas para que pudéssemos compreender seus olhares, materializados nas (re) criações, onde as diversidades foram reveladas, por meio de objetos da arte de gêneros discursivos variados, num exercício multiletrado.

\section{The genre fanzine-zine in the classroom: reading, art and superheroes}

\section{Abstract}

Readings of statements aimed at contemporary youth cultures invite teachers and researchers to look at language and its teaching from new perspectives and this is the relevance of this reflection. This article aims to discuss the representations of bodies, genders and races in FanzinesZines, produced in the classroom, based on the mottos "Tarsila and all of our Brazilianness", "Reading \& Literature" and "Super-Heroes". The proposals were defined together with the students involved (from elementary school in a state public school in Marília / SP). The research is anchored in Bakhtinian studies and proposes productions based on literacies. The reflections are based on prototyp- ical interventions and the discussions indicate possibilities for working with this genre at school, since the zine promotes agile readings and authorial productions. The results refer to the valorization of the students' voices, which reverberated their worldviews, expressed from their heroes.

Keywords: Zines. Genres. Reading. Art. Bakhtinian studies.

\section{Notas}

1 Paula (2017); Paula, Serni (2017); Paula, Luciano (2020a, 2020b, 2020c, 2020d), a partir dos estudos bakhtinianos, transportam para o contexto contemporâneo a noção de linguagem proposta pelo Círculo, que denominam como verbivocovisual, dada a sua tridimensionalidade. Segundo os estudiosos, as dimensões verbal, $\mathrm{vocal} /$ sonora e visual, constituem a linguagem e, de maneira potencial, sempre se encontram materializadas em qualquer enunciado, de que gênero for, ainda que, explicitamente, podem evidenciar uma, duas ou a síncrese entre as três dimensões (em enunciados chamados/ entendidos como verbais - como romance, bilhete, e-mail, entre outros; musicais - como as peças clássicas; visuais - como quadros, mímica etc.; verbo-vocais - como canção, por exemplo; verbo-visuais - como tira, charge, revistas, meme, entre outros; ou ainda verbo-voco-visuais - como ópera, filmes, seriados, peças teatrais, slam etc.).

2 Fundamentamo-nos nos estudos bakhtinianos e realizamos uma atividade de intervenção a partir da noção de protótipo de ensino, ancorada nos estudos sobre multiletramentos. Não constitui foco deste artigo discutir a concepção de protótipo, mas o compreendemos como um projeto didático adaptável ao contexto no qual acontece e demanda, ao passo de sua execução, a contribuição dos sujeitos envolvidos, permitindo modificações (adaptações e inserção de elementos trazidos pelos estudantes). Em outras palavras, o protótipo pensa o processo de ensino-aprendizagem vivo, pois, é produzido a partir de um plano inicial, alterado e construído na interação com os alunos, no ato da aula-evento singular. 
3 Expressão em inglês que remete a "revista barata". Pulp ou polpa em português, matéria prima para confecção de papel frágil, de baixa qualidade e semelhante ao papel do jornal. Segundo Magalhães (2018), nesse tipo de papel eram editadas as revistas de literatura popular, contendo histórias de guerra, crime, aventuras exóticas na selva, que constituíam o lazer das culturas juvenis do início do século 20.

4 Hoje, os fãs, a partir de suas experiências de leituras (de diversos gêneros) produzem variados enunciados (fanfiction, fanart, fanvideo, cosplay etc.) em seu universo, chamado como fandom, em diversos ambientes, principalmente, nas redes sociais (blog, Tumblr, site, Facebook, YouTube, entre outras).

5 Stan Lee: idealizador do Universo Cinematográfico Marvel. A Marvel Comics é, hoje, a maior editora de HQs do mundo. Em 2009, a The Walt Disney Company adquiriu a Marvel Entertainment, conforme disponível em: https://pt.wikipedia.org/wiki/Marvel_Comics. Acesso em: 28 jul. 2020.

6 Alter ego (do latim, alter: outro; ego: eu) é uma locução substantiva latina que, segundo o Dicionário Houaiss Online, significa: "1. um segundo eu; (...); 3. outro aspecto do próprio ego". Disponível em https://houaiss.uol.com. br/corporativo/apps/uol_www/v5-4/html/index. php\#1. Acesso em: 31 jul. 2020.

\section{Referências}

BRASIL. Base Nacional Comum Curricular. Brasília: MEC, 2018.

BAKHTIN, M. M. Notas sobre literatura, cultura e ciências humanas. Rio de Janeiro: Editora 34, 2017.

BAKHTIN, M. M. Os gêneros do discurso. Rio de Janeiro: Editora 34, 2016.

BAKHTIN, M. M. Teoria do Romance I - A Estilística. Rio de Janeiro: Editora 34, 2015.

BAKHTIN, M. M. Teoria do Romance II - As formas do tempo e do cronotopo. Rio de Janeiro: Editora 34, 2018.

BAKHTIN, M. M. Teoria do Romance III - O romance como gênero literário. Rio de Janeiro: Editora 34, 2019.
BAKHTIN, M M. Para uma filosofia do ato responsável. São Carlos: Pedro \& João, 2010.

BARTHES, R. O rumor da língua. São Paulo: Martins Fontes, 2004.

BAUMAN, Z. Modernidade líquida. São Paulo: Zahar, 2001.

BAUMAN, Z. Tempos líquidos. São Paulo: Zahar, 2007.

CANCLINI, N. G. Culturas híbridas: estratégias para entrar e sair da modernidade. São Paulo: EdUSP, 2013.

ORACINI, M. J. R. F. Concepções de leitura na (pós) modernidade. In: CARVALHO, R. C. de; LIMA, P. (org.). Leitura: múltiplos olhares. Campinas: Mercado de Letras, 2005. p. 15-44.

CRARY, J. 24 / 7: o capitalismo tardio ou os fins do sono. São Paulo: Ubu, 2016.

DAVIS, A. Mulheres, Raça e Classe. São Paulo: Boitempo, 2016.

FREIRE, P. Pedagogia da autonomia. São Paulo: Paz \& Terra, 1997.

FREIRE, P. Educação como prática da liberdade. São Paulo: Paz \& Terra, 2019.

GERALDI, J. W. A aula como acontecimento. São Carlos: Pedro e João, 2010.

HAN, B.-C. Sociedade do Cansaço. Rio de Janeiro: Vozes, 2014.

HAN, B.-C. Sociedade da Transparência. Rio de Janeiro: Vozes, 2017.

HAN, B-C. Hiperculturalidade: Cultura e Globalização. Rio de Janeiro: Vozes, 2019.

LIPOVETSKY, G. Os tempos hipermodernos. São Paulo: Barcarolla, 2004.

MAGALHÃES, H. P. Pedras no charco: Resistência e perspectivas do fanzine. João Pessoa: Marca da Fantasia, 2018. (versão e-book).

MEDVIÉDEV, P. N. O método formal nos estudos literários. São Paulo: Contexto, 2012.

PAULA, L. de. O enunciado verbivocovisual de animação: a valoração do "amor verdadeiro" 
Disney - uma análise de Frozen. In: FERNANDES Jr., A.; STAFUZZA, G. B. (org.). Discursividades contemporâneas: política, corpo, diálogo. Campinas (SP): Mercado de Letras, 2017. p. 287-314. Disponível em: https://www. academia.edu/41087684/O_enunciado_verbivocovisual_de_anima\%C3\%A7\%C3\%A3o_a_ valora\%C3\%A7\%C3\%A3o_do_amor_verdadeiro_Disney_uma_an\%C3\%A1lise_de_Frozen.

PAULA, L. de; SERNI, N. M. A vida na arte a verbivocovisualidade do gênero filme musical. Raído, Dourados (MS), v. 11, n. 25, p. 178-201, jan./jun. 2017. Disponível em: https://ojs.ufgd. edu.br/index.php/Raido/article/view/6507. DOI: https://doi.org/10.30612/raido.v11i25.6507.

PAULA, L. de; BARISSA, A. B. M.; OLIVEIRA, N. R. de. Produções e produtos culturais na sala-de-aula: uma análise crítico-dialógica do fandom de Harry Potter e da franquia Meu Malvado Favorito. Revista Ibero-Americana de Estudos em Educação, v. 14, n. esp. 4, p. 2071-2087. Disponível em: https://periodicos.fclar.unesp.br/iberoamericana/article/ view/12935. DOI: https://doi.org/10.21723/riaee. v14iesp.4.12935.

PAULA, L. de; LUCIANO, J. A. R. A filosofia da linguagem bakhtiniana e sua tridimensionalidade verbivocovisual. Estudos Linguísticos, São Paulo, v. 49, n. 2 p. 706-722, 2020a. Disponível em: https://revistas.gel.org.br/estudos-linguisticos/article/view/2691. DOI: https://doi. org/10.21165/el.v49i2.2691.

PAULA, L. de; LUCIANO, J. A. R. A tridimensionalidade verbivocovisual da linguagem bakhtiniana. Linha D'Água, São Paulo (SP), v. 33 , n. 3 p. $105-134,2020$ b. Disponível em: https://www.revistas.usp.br/linhadagua/article/ view/171296. DOI: https://doi.org/10.11606/ issn.2236-4242.v33i3p105-134.

PAULA, L. de; LUCIANO, J. A. R. Filosofia da linguagem bakhtiniana: concepção verbivocovisual. Revista Diálogos, Cuiabá (MT), v. 8, n. 3 p. 132-151, 2020c. Disponível em: https:// periodicoscientificos.ufmt.br/ojs/index.php/ revdia/article/view/10039.
PAULA, L. de; LUCIANO, J. A. R. Recepções do pensamento bakhtiniano no Ocidente: a verbivocovisualidade no Brasil. In: BUTURI Jr., A.; BRAA, S.; SOARES, T. B. No campo discursivo: teoria e análise. Campinas: Pontes, 2020d. Disponível em: https://www.academia. edu/44544219/Recep\%C3\%A7\%C3\%B5es_do_ pensamento_bakhtiniano_no_Ocidente_a_verbivocovisualidade_no_Brasil.

PAULA, L. de; GONÇALVES, J. de C. Gêneros Discursivos na escola: acontecimento emancipatório de leitura. Educação e Linguagens, Campo Mourão (PR), v. 9, n. 16 p. 17-52, 2020. Disponível em: http://www.fecilcam.br/revista/ index.php/educacaoelinguagens/article/viewFile/2126/1301.

PAULA, L. de; ZANDONADI, R. S. Fanfiction: leitura e escrita na era digital. Línguas \& Letras, Cascavel (PR), v. 21, n. 49 p. 86-107, 2020. Disponível em: http://e-revista.unioeste. br/index.php/linguaseletras/article/view/24332. DOI: 10.5935/1981-4755.20200005.

RIBEIRO, D. Lugar de fala. Feminismos Plurais. São Paulo: Pólen, 2019.

ROJO, R.; MOURA, E. (org.). Multiletramentos na escola. São Paulo: Parábola, 2012.

ROJO, R. Gêneros discursivos do Círculo de Bakthin e multiletramentos. In: ESCOLA conectada, os multiletramentos e as Tics. São Paulo: Parábola, 2013. p. 13-36.

ROJO, R.; BARBOSA, J. P. Hipermodernidade, multiletramentos e gêneros discursivos. São Paulo: Parábola, 2015.

SAFFIOTI, H. I. B. O poder do macho. São Paulo: Moderna, 1987.

VOLÓCHINOV, V. Marxismo e Filosofia da Linguagem. Rio de Janeiro: 34, 2017.

VOLOCHINOV, V. A construção da enunciação e outros ensaios. São Carlos: Pedro \& João, 2013. 